University of Nebraska - Lincoln

DigitalCommons@University of Nebraska - Lincoln

Other Publications in Zoonotics and Wildlife

Disease

Wildlife Disease and Zoonotics

1995

\title{
Rodent-Borne Hemorrhagic Fever Viruses: A Special Risk for Mammalogists?
}

James E. Childs

Centers for Disease Control and Prevention, james.childs@yale.edu

James N. Mills

Centers for Disease Control and Prevention

Gregory E. Glass

John Hopkins University

Follow this and additional works at: https://digitalcommons.unl.edu/zoonoticspub

Part of the Veterinary Infectious Diseases Commons

Childs, James E.; Mills, James N.; and Glass, Gregory E., "Rodent-Borne Hemorrhagic Fever Viruses: A Special Risk for Mammalogists?" (1995). Other Publications in Zoonotics and Wildlife Disease. 86.

https://digitalcommons.unl.edu/zoonoticspub/86

This Article is brought to you for free and open access by the Wildlife Disease and Zoonotics at DigitalCommons@University of Nebraska - Lincoln. It has been accepted for inclusion in Other Publications in Zoonotics and Wildlife Disease by an authorized administrator of DigitalCommons@University of Nebraska - Lincoln. 


\title{
RODENT-BORNE HEMORRHAGIC FEVER VIRUSES: A SPECIAL RISK FOR MAMMALOGISTS?
}

\author{
James E. Childs, James N. Mills, and Gregory E. Glass
}

Viral and Rickettsial Zoonoses Branch, National Center for Infectious Diseases, Centers for Disease Control and Prevention, 1600 Clifton Road NE, Atlanta, GA 30333 (JEC, JNM)

Department of Molecular Microbiology and Immunology, Johns Hopkins University, School of Hygiene and Public Health, 615 North Wolfe Street, Baltimore, MD 21205 (GEG)

We review two groups of taxonomically unrelated viruses that share similarities in host preference and transmission routes to humans and pose a risk for mammalogists working with rodents. The rodent-borne hemorrhagic fever viruses in the Arenaviridae and Bunyaviridae are widely distributed on most continents where rodents occur. Their geographic distribution usually exceeds the distribution of the recognized human diseases they cause and has resulted from either natural coevolutionary events or the dissemination of viral passengers traveling with introduced mammalian hosts. Diseases of humans caused by these agents are among the most severe and most frequently fatal of zoonotic diseases. These viruses show remarkable specialization in the limited number of rodent species in which they naturally occur and frequently establish persistent infections in individual hosts that can result in variable effects on growth, reproduction, and survival of hosts. Our knowledge of these viruses, their hosts and geographical range, and the pathophysiological consequences of infection are incompletely understood and offer a rich area of study for naturalists interested in host-parasite coevolution.

Key words: Bunyaviridae, Arenaviridae, zoonoses, Hantavirus, reservoir, hantavirus pulmonary syndrome

Rodents are reservoir hosts for many viral agents. However, two groups of RNA viruses have evolved particularly close relationships with their rodent hosts and, when transmitted to humans, can cause severe disease termed hemorrhagic fever. Viruses within the family Arenaviridae and within the genus Hantavirus (family Bunyaviridae) are phylogenetically distinct; yet, they share numerous traits. Each virus typically is associated with one or a few species of rodent hosts. These agents can establish persistent infections in the host with virus continuously or sporadically shed into the environment via secreta or excreta. Although mechanisms and characteristics of viral persistence established by these two groups vary, their epidemiologic consequences can be remarkably similar. Epidemics of hemorrhagic fever in humans are associated with increased densities of reservoir species, and risk of human infection varies with occupation and degree of contact with the host.

A review of rodent-borne hemorrhagic fever viruses is timely because of the concern among professional mammalogists over the identification of hantavirus pulmonary syndrome (HPS) associated with Sin Nombre virus (SNV; formerly Muerto Canyon virus) which has been isolated from Peromyscus maniculatus captured in the southwestern United States. However, none of the virus-rodent associations and the diseases they cause in humans are likely to be truly "new," regardless of the date of discovery or first clinical description. We hope this review will provide mammalogists with a better knowledge of these rodent-borne viruses, their reservoirs, and the diseases 
TABLE 1.-Current status of the hantaviruses isolated in cell culture, their geographic distribution, primary mammalian host, and associated human disease.

\begin{tabular}{|c|c|c|c|}
\hline Virus & Distribution & Primary host & Disease $^{a}$ \\
\hline Sin Nombre & $\begin{array}{l}\text { Western and midwestern } \\
\text { United States }\end{array}$ & Peromyscus maniculatus & HPS \\
\hline Blackwater Creek Canal & $\begin{array}{l}\text { Southeastern United } \\
\text { States }\end{array}$ & Sigmodon hispidus & HPS \\
\hline Prospect Hill & $\begin{array}{l}\text { Eastern and midwestern } \\
\text { United States }\end{array}$ & Microtus pennsylvanicus & Not described \\
\hline Hantaan & Rural Asia & Apodemus agrarius & HFRS (severe) \\
\hline Seoul & Worldwide & Rattus norvegicus & HFRS (mild) \\
\hline Dobrava-Belgrade & Balkans & Apodemus flavicollis & HFRS (severe) \\
\hline Puumala & $\begin{array}{l}\text { Scandinavia, Russia, Eu- } \\
\text { rope, Balkans }\end{array}$ & Clethrionomys glareolus & HFRS (mild; NE) \\
\hline Thailand & Thailand & Bandicota indica & Not described \\
\hline Thottapalayam & India & Suncus murinus & Not described \\
\hline
\end{tabular}

${ }^{\text {a }}$ HPS = hantavirus pulmonary syndrome; HFRS = hemorrhagic fever with renal syndrome; NE = nephropathia epidemica.

they cause, and stimulate additional study of these biologically fascinating and medically important viruses and their hosts.

\section{HANTAVIRUSES}

Human diseases caused by hantaviruses.-Hantaviruses are important agents of human disease throughout Eurasia, where different viruses cause ca. 1-2 $\times 10^{5}$ cases of hantaviral disease annually (Lee, 1989). Old World hantaviruses cause several diseases, collectively called hemorrhagic fever with renal syndrome (HFRS), that first came to the attention of physicians and biologists from the United States during the Korean War, when United Nations troops were diagnosed with Korean hemorrhagic fever (KHF). KHF, typical of the severe form of HFRS, is characterized by increased capillary permeability leading to hemorrhage and acute shock, frequently accompanied by renal failure, and had a case fatality of 5-10\% (Gajdusek, 1989).

In 1993, the first outbreak of severe human disease (HPS) associated with a hantavirus in the Western Hemisphere was diagnosed in the southwestern United States. HPS is characterized initially by fever, myalgia, headache, nausea, and vomiting accompanied by a cough and difficulty breathing. This leads in a few hours or days to a sudden and dramatic respiratory dis- tress syndrome (Duchin et al., 1994). The degree of respiratory involvement in HPS makes it unique among hantaviral diseases, although pulmonary disease is seen in patients in Sweden who have nephropathia epidemica (NE), a hantavirus disease caused by Puumala virus (PUUV; Linderholm et al., 1992). The mortality associated with HPS $(>50 \%)$ is by far the highest reported for any hantavirus disease (typically $<10 \%$ ), although this may decline as disease surveillance improves.

Characteristics of hantaviruses.-In 1976, antigen, which reacted with sera from patients who had recovered from KHF, was identified in the lungs of striped field mice, Apodemus agrarius (Lee et al., 1978). After isolation in cell culture, the virus, named Hantaan virus (HTNV), was identified as the prototype virus of a new genus within the family Bunyaviridae (Schmaljohn et al., 1985). Currently, there are at least nine members of the genus Hantavirus, each, with the exception of Thottapalayam, primarily associated with a single genus of rodents (Table 1). The viral genome contains three single-stranded RNA segments of negative sense (Schmaljohn et al., 1986, 1987). On the basis of antigenic and genetic similarities, hantaviruses are distinct from other genera of the Bunyaviridae. 
Natural history and epizootiology.-The four hantaviruses isolated from rodents in the United States are: SNV, a causative agent of HPS in the Southwest, isolated from deer mice (Peromyscus maniculatus; Elliott et al., 1994); Black Creek Canal virus (BCCV; Rollin et al., in press), a causative agent of HPS in Florida, isolated from Sigmodon hispidus; Seoul virus (SEOV), a causative agent of mild HFRS (Lee et al., $1982 a$ ), isolated from Norway rats (Rattus norvegicus); Prospect Hill virus (PHV), isolated from meadow voles (Microtus pennsylvanicus; Lee et al., 1985) and not identified as a human pathogen (Table 1). Other novel hantaviruses, or strains of existing hantaviruses, have caused HPS or similar disease in Louisiana and Rhode Island; these viruses are not yet isolated in cell culture and their rodent hosts are unknown (Centers for Disease Control and Prevention, 1994a). These latter agents have been identified by using reverse transcriptasepolymerase chain reaction (RT-PCR) and genetic sequencing of products obtained from tissues of infected humans, an approach used to initially identify SNV (Nichol et al., 1993). Additional strains of hantavirus have been identified by RT-PCR from Reithrodontomys megalotis in New Mexico and from Microtus californicus in California, but their pathogenic characteristics have not been established (B. Hjelle, pers. comm.; Hjelle et al., 1994).

HTNV, associated with A. agrarius, is responsible for most of the severe type of HFRS reported from Europe and Asia (LeDuc, 1987). Apodemus flavicollis is host for Dobrava/Belgrade virus, which causes a severe form of HFRS in the Balkans. PUUV, associated with the genus Clethrionomys in Europe and Russia, causes the milder form of HFRS, known as NE (LeDuc, 1987). Although Clethrionomys occurs in the United States and Canada, PUUV has not been identified from the genus.

In contrast to human infection, infection in rodent hosts causes little or no pathology, as demonstrated by experimental studies of HTNV in A. agrarius (Lee et al., 1981), PUUV in Clethrionomys glareolus (Yanagihara et al., 1985a), and SEOV in $R$. norvegicus (Tanishita et al., 1986). SEOV in $R$. norvegicus had no detrimental effect on survival, reproductive fitness, or weight gain (Childs et al., 1989).

Hantaviruses establish a persistent infection in the primary host that is characterized by long-term shedding of virus via urine, feces, or saliva (Lee et al., 1981; Yanagihara et al., 1985a). Although viral persistence for SNV in P. maniculatus has not been shown directly, RT-PCR detection of viral RNA in antibody-positive rodents suggests these hosts also are infected persistently (Childs et al., 1994). Although infections are persistent, even in situations in which extensive temporal and spatial overlap of rodent hosts infected with two different hantaviruses occurs, there is little evidence of cross-species infection (Korch et al., 1989).

Virus transmission.-Hantaviruses are believed to be transmitted from rodents to humans by the inhalation of small-particle aerosols of virus-contaminated excreta or secreta (Tsai, 1987). The best support of a respiratory route of transmission comes from laboratory-associated outbreaks of hantavirus disease, in which many infected individuals never visited rooms where rodents were housed (Kulagin et al., 1962). Arthropod vectors are not believed to be epidemiologically important, although they may become infected by feeding on viremic hosts. Rodent bite has been implicated as a route of rodent-to-human transmission (Dournon et al., 1984) and of rodent-to-rodent transmission (Glass et al., 1988). Laboratory studies have demonstrated that rodents can be infected by aerosol challenge, but they may be more susceptible to intramuscular inoculation, such as might occur by a severe bite (Nuzum et al., 1988).

Epidemiology.-With the exception of SEOV, hantaviruses are maintained by rodents found mostly in rural settings. Species 
such as $C$. glareolus frequently are associated with forest habitats, while $A$. agrarius and $P$. maniculatus commonly are found in grasslands and cultivated fields in addition to woodlands. HFRS, strongly associated with the occupation of farming, predominantly affects adult males with peaks in incidence during autumn-spring in Korea and China (Hua-Xin and Fu-Xi, 1993; Lee, 1982).

In the United States, cases of HPS have occurred equally in males and females, suggesting a different epidemiologic process from HFRS (Centers for Disease Control and Prevention, 1993a). Perhaps the tendency of $P$. maniculatus to enter human dwellings results in more equal risk between the sexes. Most cases of HPS have occurred during summer months. The finding that many of the first recognized cases of HPS occurred in Native Americans presumably is linked to a rural lifestyle (Zeitz et al., 1995).

Urban cases of HFRS led to the discovery of SEOV in Korea (Lee et al., 1982a). This serogroup of hantavirus has the greatest geographic distribution as $R$. norvegicus and Rattus rattus have been introduced around the world. Infected rats are common in the United States (Childs et al., 1987b) and elsewhere (LeDuc et al., 1986). The mild form of HFRS caused by SEOV is common in China, and incidence in cities peaks during spring (Hua-Xin and $\mathrm{Fu}-\mathrm{Xi}$, 1993). For reasons that are not clear, outbreaks of urban HFRS have not occurred in the United States or in many regions where infected rats are found. SEOV infection in Baltimore resulted in a mild illness characterized by fever, nausea, and abnormalities in renal and liver function as in Asia (Glass et al., 1993). Human infection with SEOV, as indicated by antibodies, also has been associated with chronic renal disease and hypertension in Baltimore (Glass et al., 1993).

The final epidemiologic pattern of hantavirus disease is the occurrence of laboratory outbreaks of HFRS. Outbreaks asso- ciated with exposure to rats have been reported for workers in research institutes (Desmyter et al., 1993; Lee and Johnson, 1982; Lloyd et al., 1984; Umenai et al., 1979). In Russia, an outbreak involving 113 persons, most of whom never entered the room in which rodents were housed, occurred in $<2$ months after wild-caught rodents were brought into laboratory facilities (Kulagin et al., 1962). The implications of this for researchers working on laboratory colonies derived from wild-caught rodents in the United States are obvious. Hantavirus-infected colonies of laboratory rats have been cleared of contamination by caesarian section and cross-fostering of young on virus-free females (McKenna et al., 1992).

In addition to wild-caught rodents, cell lines and tissues derived from infected animals can be a source of human hantavirus infection (Lloyd and Jones, 1986). Any procedures that involve the cryo-preservation of rodent tissues at $\leq-70^{\circ} \mathrm{C}$ will preserve infectious virus.

Prevalence of infections in rodents.The most commonly infected rodent found in the investigation of the initial outbreak of HPS in Arizona, New Mexico, and Colorado, was $P$. maniculatus, with an antibody prevalence based on serologic testing with PHV antigens of $30.4 \%(n=813$; Childs et al., 1994). Evidence of infection also was found in $19.6 \%$ of 275 Peromyscus truei and $6.8 \%$ of 51 Peromyscus boylii. Other genera of rodents that had relatively high antibody prevalence to PHV antigen included three species of Tamias (overall prevalence of $6.1 \%, n=215$ ) and $R$. megalotis $(22 \%, n=9)$. The antibody prevalence among $P$. maniculatus from other regions of the country is lower than that found in the Southwest in 1993 (T. G. Ksiazek et al., pers. comm.). In Kansas, 17 of 201 (8.5\%) $P$. maniculatus were infected (Kaufman et al., 1994).

In Florida, prevalence of antibody reactive with SNV antigens was $13 \%$ among 90 $S$. hispidus trapped in Dade Co. (Centers for Disease Control and Prevention, 1994a). 
Because BCCV was isolated from two of these animals (Rollin et al., in press), the presumption is that all or most of the infection was caused by this new virus.

Detailed investigations of SEOV in the United States have shown that infected Norway rats are widely distributed in port cities, including Philadelphia, Houston, New Orleans, and Baltimore (Childs et al., 1987a; LeDuc et al., 1984; Tsai et al., 1985). The full extent of SEOV infection within the continental United States has never been completely explored, although seropositive animals have been found from the inland cities of Cincinnati and Columbus, Ohio (Tsai et al., 1985).

In Baltimore, SEOV infection was enzootic (Childs et al., 1985) and relatively stable in populations of rats sampled during a 10-year period (Childs et al., 1987a; Korch et al., 1989). This epidemiologic pattern coupled with the limited movement of rats in urban environments (Davis et al., 1948) suggests that the introduction of SEOV was not a recent event. This was supported by genetic analyses of hantaviral strains recovered from $R$. norvegicus in the United States and of prototype SEOV (Arthur et al., 1992; Xiao et al., 1992).

The major native reservoir for PHV is Microtus pennsylvanicus, but other Microtus also have antibodies to hantaviruses (Yanagihara et al., 1987). Recent evidence suggests that $M$. californicus hosts a virus closely related, but distinct from PHV (B. Hjelle, pers. comm.). Detailed virologic or serologic surveys of hantavirus activity in M. pennsylvanicus are limited to a few locations in the states of Maryland, Minnesota, and Wisconsin, where PHV has been isolated (Burek et al., 1994; Korch et al., 1989; Lee et al., 1985; Yanagihara et al., 1987). In these locations, antibody prevalence to PHV among $M$. pennsylvanicus was $15-27 \%$ (Burek et al., 1994; Korch et al., 1989; Lee et al., 1985; Yanagihara et al., 1987). Other voles with antibody to a hantavirus include Clethrionomys rutilus captured from Alaska (Lee et al., 1982b) and Clethrionomys gapperi from West Virginia (Yanagihara et al., 1987).

Human infection with hantavirus in the United States.-Serosurveys had established the presence of antibodies to hantaviruses in humans in North America prior to the outbreak of HPS in 1993. These studies are difficult to compare because sensitivity and specificity vary among the serologic tests used. In addition, antibody to hantavirus may be cross-reactive among serotypes, and, therefore, the infecting virus can be difficult to identify with serologic means alone. However, antibodies to hantaviruses were found among shipyard workers (4 of 65 Baltimore longshoremen and 8 of 265 New Orleans granary employeesTsai et al., 1985), forestry workers ( 1 of 85 from Mississippi, 1 of 79 from Virginia and 9 of 360 from Alaska-Forthal et al., 1987), blood donors (6 of 664 from Maryland and West Virginia), patients with febrile illnesses of unknown origin ( 7 of 1,035 from Colorado, North Carolina, Hawaii, and Texas-Yanagihara et al., 1985b), and from emergency room and sexually transmitted disease clinics (15 of 6,060 from Maryland-Glass et al., 1993). In Canada, 29 of 2,063 sera from healthy individuals from 10 provinces were positive (Lee et al., 1984). None of these North American surveys documented any significant association between presence of antibody and illness compatible with HFRS.

Human infection by PHV has been suggested by a serosurvey of professional mammalogists (four of 203 positive). These individuals had from 10 to 25 years of field experience with microtine rodents in the midwestern, southeastern, and southwestern United States, but none reported a prior illness suggestive of HFRS (Yanagihara et al., 1984). However, antibodies to PHV crossreact with SNV (Childs et al., 1994) and clinical HPS is substantially different from HFRS, so the conclusions from this study must be reevaluated.

Rodent populations and human infection.-Over broad geographic regions, 
TABLE 2.-Arenaviruses pathogenic for humans, their geographic distribution, primary host, and associated human disease.

\begin{tabular}{llll}
\hline \multicolumn{1}{c}{ Virus } & \multicolumn{1}{c}{ Distribution } & \multicolumn{1}{c}{ Primary host } & \multicolumn{1}{c}{ Disease } \\
\hline $\begin{array}{l}\text { Lymphocytic choriomenin- } \\
\text { gitis virus }\end{array}$ & Worldwide & Mus musculus & Lymphocytic choriomeningitis \\
Lassa virus & West Africa & Mastomys & Lassa fever \\
Junín virus & Central Argentina & Calomys musculinus & Argentine hemorrhagic fever \\
Machupo virus & Northeastern Bolivia & Calomys callosus & Bolivian hemorrhagic fever \\
Guanarito virus & Northwestern Venezuela & Sigmodon alstoni & Venezuelan hemorrhagic fever \\
Sabía virus & Sao Paulo State, Brazil & Unknown & Not named \\
\hline
\end{tabular}

abundance of rodents has been linked to outbreaks of hantavirus disease. At some locations on the Sevilleta Research Station in Socorro Co., New Mexico, populations of Peromyscus were $30 \mathrm{mice} / \mathrm{ha}$ in May 1993 , but declined to $<3 /$ ha by August, at the time the outbreak of HPS was waning (Parmenter and Vigil, 1993). In Sweden, cases of $\mathrm{NE}$ correlated significantly with abundance of small rodents from 1959 to 1975 (Nyström, 1982). A more recent study in Sweden and European Russia found a positive correlation, although not statistically significant, between cases of $\mathrm{NE}$ and abundance of bank voles (Niklasson et al., 1993). In Finland, the prevalence of hantavirus infection among voles was positively associated with the abundance of voles and both of these factors were linked to outbreaks of NE (Brummer-Korvenkontio et al., 1982).

Risk factors. - Of the 107 cases of HPS identified in the United States as of May 1995, three have occurred in wildlife biologists-mammalogists (L. Armstrong, pers. comm.). In Canada, one of the three cases of HPS identified was a wildlife biologist who trapped mammals (Health Canada, 1994). Additional information showed contact with rodents to be a predisposing risk factor for HPS (Zeitz et al., 1995). Efforts to quantify the risk of hantaviral infection in persons with occupational exposure to rodents are ongoing (L. Armstrong et al., in litt.). In Finland, no mammalogist with $<5$ years of experience had antibodies to PUUV, but $40 \%$ of those who trapped voles for $>10$ years had antibody (BrummerKorvenkontio et al., 1982).

In an HPS case-control study, small rodents were more abundant in case households than in control households (Zeitz et al., 1995). Agricultural activity, household cleaning, and trapping rodents also were significantly associated with HPS (Zeitz et al., 1995). The only occupation associated with HPS was being a herder, which requires opening and cleaning seasonally used shelters. Opening of seasonally used dwellings by vacationers also is a risk factor for acquiring $\mathrm{NE}$ in Scandinavia (LeDuc, 1989).

Strategies aimed at habitat modification (e.g., reducing shelter, food sources, and access to human dwellings) and population control of rodents (i.e., trapping and use of appropriate rodenticides) may reduce exposure to hantavirus. Personal protection, such as rubber gloves, should be used when performing certain activities, as detailed in a separate document (Centers for Disease Control and Prevention, 1993b). Because trapping rodents may be a risky behavior (Zeitz et al., 1995), carcasses and traps should be disinfected before handling and appropriate disposal (Centers for Disease Control and Prevention, 1993b).

\section{ARENAVIRIDAE}

Arenaviruses (Table 2) are single-stranded, negative-sense RNA viruses, containing two RNA segments. All arenaviruses are broadly cross-reactive by immunofluorescent antibody tests, but may be readily dis- 
tinguished by using more specific plaquereduction-neutralization assays (Peters, 1991). Of the 16 known arenaviruses, 15 are associated with rodent hosts, the exception being Tacaribe virus, which is associated with bats of the genus Artibeus in Trinidad and the West Indies (Downs et al., 1963). Lassa virus, from West Africa, and lymphocytic choriomeningitis virus (LCMV), distributed worldwide, are Old World forms. The rest are distributed in the Americas, forming the Tacaribe complex (Fig. 1). Besides LCMV, which was introduced with its host, Mus musculus, Tamiami virus (Calisher et al., 1970) is the only arenavirus known from the United States. Tamiami virus has been isolated from $S$. hispidus in Florida and is not associated with any human disease.

Human diseases caused by arenaviruses.-Lymphocytic choriomeningitis (LCMV) causes a meningitis or influenzal syndrome, which rarely is serious. A typical case begins with fever, muscle aches, retroorbital headache, weakness, and loss of appetite. Convalescence may occur after ca. 1 week, or a temporary remission may be followed by worsening symptoms, including increasing fever, headache, and neurologic involvement. Even in these cases, complete recovery is the usual course. Asymptomatic infection is common (Peters, 1991).

Five arenaviruses are known to cause hemorrhagic fever: Lassa virus causes Lassa fever in West Africa; Junín virus (JV) causes Argentine hemorrhagic fever; Machupo virus causes Bolivian hemorrhagic fever; Guanarito virus causes Venezuelan hemorrhagic fever; Sabiá virus is known from a single naturally acquired case in Brazil. The arenaviral hemorrhagic fevers generally have an insidious onset involving fever, malaise, muscle aches, and retroorbital headache. These may be followed by hypotension, conjunctival injection, bleeding from the gums, and petechiae on the palate, fauces, chest, and axillae. Neurologic signs such as tremors, dizziness, and coordination problems are common with the
South American hemorrhagic fevers, but less common with Lassa fever. During the 2nd or 3rd week of illness, patients will begin to recover or may deteriorate with the development of extensive petechial hemorrhages, bleeding from mucous membranes, hypotension and shock, coma, and convulsions (Peters, 1991). Mortality is 10-30\% among untreated patients.

Natural history and epizootiology.-Depending upon the dose and route of infection, age, species, and probably genetics of the host, infection of a rodent with an arenavirus may result in transient viremia, followed by development of antibody and subsequent clearing of the infection. Alternatively, as with hantaviruses, infection may result in a chronic carrier state, with infected rodents shedding virus in urine, feces, and saliva for an extended period. Another parallel with hantavirus infection is the demonstration, in some cases, of large quantities of viral antigen in tissues or body fluids in spite of the presence of circulating antibody. Laboratory studies have shown that the effect of chronic infection varies with virus and host species.

Although there is little or no overt disease, reproductive success may be affected in infected hosts. In the Calomys callosusMachupo virus model, chronically infected females are essentially sterile. Thus, Machupo infection is hypothesized to be an important driving force in reservoir population dynamics (Johnson, 1985). In the Calomys musculinus-Junín virus model, however, although growth and reproductive success are diminished in laboratory-reared females that are infected as sucklings, females infected as adults have normal litters (Vitullo and Merani, 1990). Therefore, vertical transmission would result in detrimental population phenomena, while horizontal transmission would not. Evidence from field studies indicates that much of the viral transmission within populations of C. musculinus is horizontal, occurring between adult animals. As was shown for SEOV and $R$. norvegicus, there was no difference in 


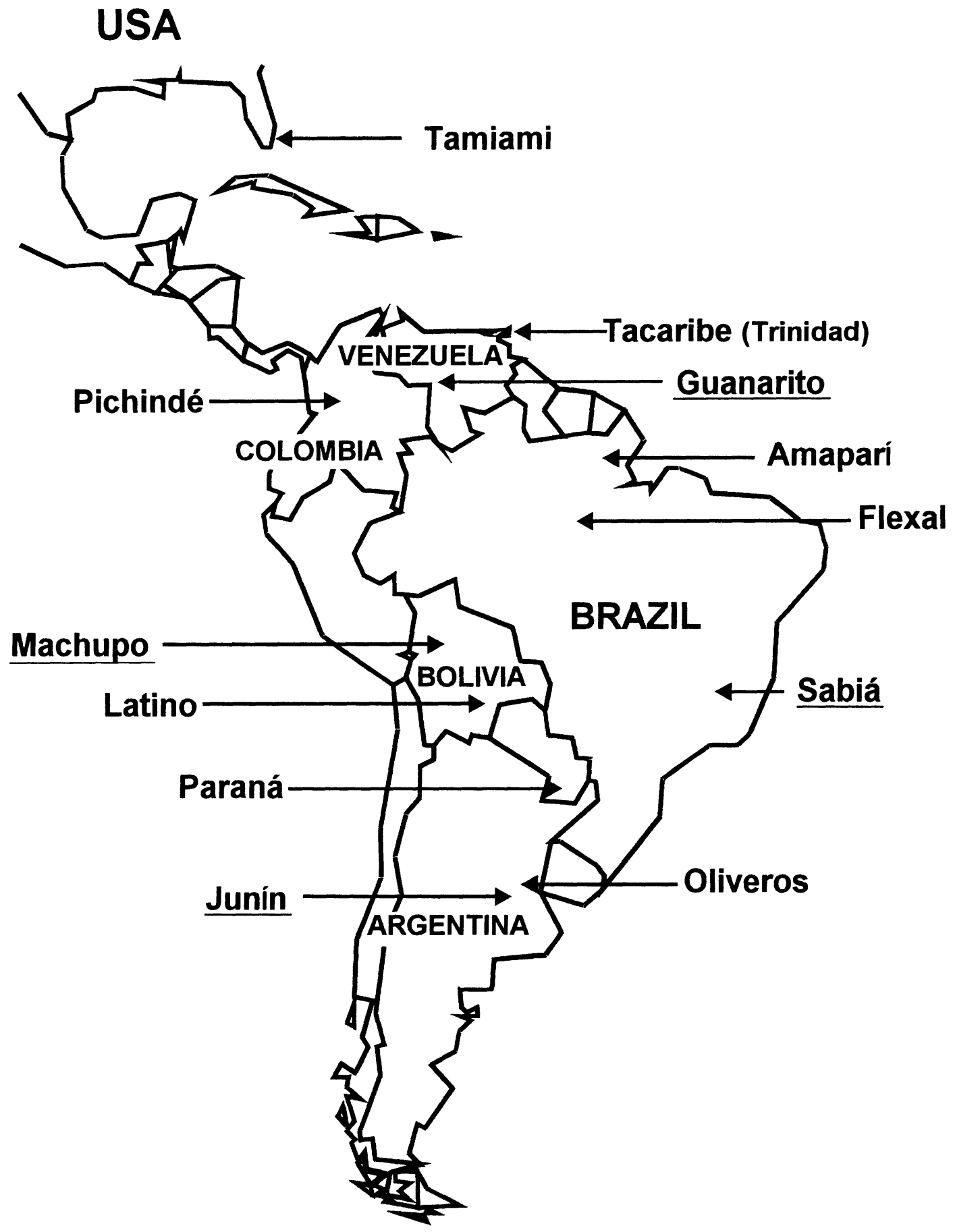

FIG. 1.-Geographic distribution of the known arenaviruses in the New World. Known human pathogens are underlined. 
mean mass, growth rates, or survivorship between infected and uninfected $C$. musculinus captured in the field. Further, infection with JV was positively associated with mass and age, as well as with the male sex, and the presence of scars (Mills et al., 1992, 1994). This pattern implicates aggressive encounters among large, adult, male mice as a mechanism of transmission for $\mathrm{JV}$. Nonaggressive mechanisms of horizontal transmission also might be important and could include aerosol, mutual grooming, direct contact with infected secretions or excretions, or venereal routes. Laboratory studies demonstrated that aerosol transmission of JV occurred infrequently between cages, but transmission occurred commonly among mice maintained in the same cage (Sabattini et al., 1977).

Epidemiology.-LCMV, the prototype arenavirus, was isolated in 1933 during an epidemic of encephalitis in St. Louis, Missouri (Armstrong and Lillie, 1934). LCMV is exceptional among arenaviruses in that it causes a meningitis or influenzal syndrome, which rarely is serious and it occurs nearly worldwide in association with its primary host, Mus musculus. Antibody prevalence was $1-5 \%$ among human populations in Europe and the United States (Childs and Peters, 1993; Johnson, 1989). Infection may be more common in rural populations or in lower socioeconomic, urban groups. Infection in populations of mice may be highly focal, with prevalences reaching $\geq 50 \%$ in mouse-infested, inner-city households (Childs et al., 1992). Some outbreaks have been associated with exposure to hamsters, which may develop a transient carrier state (Johnson, 1989).

Colonies of laboratory animals may become chronically infected and personnel working with LCMV or with potentially infected mice or hamsters are at increased risk for infection. From 1952 to 1966,45 infections, including five that resulted in death, were documented (Sulin and Pike, 1969), and laboratory infections probably are more common than reported. The most common mode of transmission of LCMV from rodent to man is unclear, but might occur by any of three mechanisms: inhalation of infectious aerosol; consumption of contaminated food and drink; direct contact of infected materials with broken skin or mucous membranes.

Lassa fever was first described in 1969 from a case in the town of Lassa, Nigeria. Initially believed to be a rare and frequently fatal disease, Lassa fever is now recognized to be common in West Africa, with casefatality ratios of ca. $1 \%$ and numerous inapparent infections. Nevertheless, Lassa fever may be the major cause of death in West Africa, with ca. 100,000-300,000 cases and 5,000 deaths/year (McCormick et al., 1987). Lassa virus has been isolated from humans or rodents in Nigeria, Sierra Leone, Guinea, and Liberia, but serologic surveys show that Lassa or Lassa-like viruses are present in at least 10 other African countries (Johnson et al., 1981; Peters, 1991). At least 20 imported cases have occurred in Europe, Asia, and North America (Cooper et al., 1982; Holmes et al., 1990; Monath, 1990; Woodruff et al., 1973).

The primary reservoir for Lassa virus is mice in the genus Mastomys. Rodents of this species complex occur in or near human dwellings and frequently are captured for food. Prevalence of Lassa virus antibody among rodents captured from homes in 15 villages in the endemic area was from 0 to $80 \%$ while the prevalence among human populations ranged from 8 to $52 \%$ (McCormick et al., 1987). The fact that all age groups and both sexes are affected equally indicates that Lassa fever is acquired in a peridomestic setting. Such a transmission pattern would lend itself to disease control through education, sanitation, and rodent control in peridomestic areas.

Human infection with Lassa virus probably is due to direct contact of virus-contaminated soil, litter, or fomites with broken skin or mucous membranes, or by ingesting uncooked rodent flesh or other contaminat- 
ed food or drink (Johnson, 1989). Nosocomial outbreaks of Lassa fever have been common.

The epidemiology and ecology of Junín virus, etiologic agent of Argentine hemorrhagic fever (AHF), are the best studied of any of the South American hemorrhagic fever viruses. JV was first described from an epidemic centered around the town of Junín, in Buenos Aires Province, Argentina (Arribalzaga, 1955). AHF now occurs in a well-defined area, ca. $120,000 \mathrm{~km}^{2}$, in parts of four provinces (Santa Fé, Buenos Aires, Córdoba, and La Pampa) on the pampas of central Argentina (Maiztegui et al., 1986). AHF primarily affects rural, male farm workers in the 20- to 40-year-old age group. Before the introduction of a newly developed vaccine in 1991, there were 200$>1,000$ cases/year (Carballal et al., 1988). Annual AHF outbreaks occur in autumn and coincide with harvest of principal summer crops (corn, sunflowers, and soybeans) and with the peak density of the primary rodent reservoir, the corn mouse (Calomys musculinus; Mills et al., 1991). Prevalence of infection in C. musculinus varies greatly among localities (e.g., 0-57\%-Sabattini and Contigiani, 1982) and over time at a given locality (e.g., $0->20 \%$-Mills et al., 1994). Transmission to humans is believed to occur via inhalation of aerosolized virus when contaminated soil and plant litter are stirred up during the mechanized harvesting process.

The corn mouse rarely enters human dwellings and its widespread occurrence in natural and cultivated habitats makes control measures problematic. C. musculinus often resides in the relatively stable border habitats (e.g., fencelines and roadsides) while its rarely infected congener, C. laucha, is more restricted to crop habitats (Mills et al., 1992). This distributional pattern raises new questions concerning the place and mechanism of transmission of JV and calls into question the policy of encouraging growth of border habitats to favor populations of other species that com- pete with $C$. musculinus (De Villafañe et al., 1977; Kravetz, 1977).

Machupo virus, the etiologic agent of Bolivian hemorrhagic fever (BHF), was isolated in 1965, following outbreaks of acute hemorrhagic fever in several small towns in rural, northeastern Bolivia, an area dedicated to subsistence agriculture and cattle raising. The endemic area includes the provinces of Itenez, Mamore, and Yacuma in the department of Beni (Pan American Health Organization, 1982). BHF has a history of striking small towns with devastating intensity. In one outbreak, 107 of 600 residents of Orobayaya were infected and 44 died (Mackenzie et al., 1964). Similar outbreaks have occurred elsewhere (Centers for Disease Control and Prevention, 1969; Mercado, 1975). Epidemics have been somewhat seasonal, with most cases occurring during the dry season, at the peak of agricultural activity (Pan American Health Organization, 1982).

The primary reservoir of Machupo virus was considered to be Calomys callosus, although recent studies have raised questions about the taxonomy of the species within the BHF-endemic area (T. L. Yates, pers. comm.). C. callosus has adapted well to human alterations of the environment. It is associated with cultivated and peridomestic habitats and frequently enters homes. This pattern of occurrence has led to successful attempts to control disease by trapping and poisoning rodents in peridomestic areas. A severe epidemic in San Joaquín abruptly ended after 2 weeks of trapping C. callosus in homes (Kuns, 1965; Mackenzie, 1965). Prevalence of infection in populations of Calomys may be high. Virus was isolated from 13 of 17 animals trapped in or near homes during the outbreak in San Joaquín (Webb et al., 1967). A campaign of monitoring, trapping, and poisoning populations of rodents throughout the endemic area apparently has been effective in keeping the incidence of BHF in check. No case was reported from 1975 to 1993 , but one case was confirmed in 1993. Seven of nine cases 
confirmed in 1994 occurred within a single family and probably represent a single index exposure, followed by secondary transmission to family members (Centers for Disease Control and Prevention, 1994c).

Person-to-person transmission of South American hemorrhagic fever viruses is rare. The apparent secondary transmission to six family members (Centers for Disease Control and Prevention, 1994c) and a nosocomial outbreak of BHF involving six cases (Peters et al., 1971) are exceptional.

Collaborative efforts are now underway between the governments of Bolivia and Argentina to test the efficacy of the AHF vaccine against $B H F$. Such a vaccine would be of use for high-risk groups such as Bolivian rodent-control workers (because many immune technicians who made up the original trapping teams have now retired) and mammalogists working in the BHF-endemic area.

The first cases of Venezuelan hemorrhagic fever (VHF) were recognized in 1989 from the town of Guanarito, on the Venezuelan llanos (Salas et al., 1991). A study of the rodent populations in the VHF endemic area revealed that $47 \%$ of Sigmodon alstoni yielded isolates of Guanarito virus while only $11 \%$ of Zygodontomys brevicau$d a$ yielded isolates. Sigmodon that yielded virus never had antibody, whereas $75 \%$ of the Zygodontomys with virus also had antibody. This suggests that $S$. alstoni develops a persistent, nonimmunizing infection and acts as the principal rodent reservoir for Guanarito virus (Tesh et al., 1993).

The VHF-endemic area is in seasonally inundated grassland in northwestern Venezuela and is occupied primarily by farmers and cattle ranchers. Infected rodents have been found throughout most of Portuguesa State as well as adjacent areas of the states of Barinas and Cojedes (R. Tesh, pers. comm.). The fatality rate for 104 clinically identified cases in 1990-1991 was 25\%. Homes within the endemic area have a high relative permeability to rodents, and Guanarito virus was isolated from a $S$. alstoni captured within the home of a case-patient. These data, combined with the even distribution of cases among sexes and age groups, suggest that infection may be acquired in or near the home, as with Lassa fever and BHF. The widespread distribution of the genus Sigmodon (midwestern United States through northern South America) underscores the importance of understanding the ecologic and physiologic factors that may limit the distribution of this virus within populations of rodents. Tamiami virus has been isolated from $S$. hispidus in the United States, although no human disease has been described.

Sabiá virus was first isolated in 1990 and is named after the Brazilian community where the index case-patient, a 25-year-old female agricultural engineer, became ill (Coimbra et al., 1994). She worked primarily in an office but, during the 10 days preceding her illness, had visited two nearby cities with family and friends. Two infections since the initial case have been laboratory acquired. Both were researchers working on the characterization of the virus (Centers for Disease Control and Prevention, 1994b; Vasconcelos et al., 1993). The reservoir and mode of transmission for Sabiá virus are unknown.

Rodent populations and human infection.-Although much of the evidence is anecdotal, there appears to be a link between reservoir density and human disease. During the trapping effort that ended the San Joaquín outbreak of BHF, nearly 3,000 Calomys callosus (ca. 10/household) were captured during a 3-week period (Mercado, 1975). A longitudinal study of populations of Calomys musculinus in the AHF-endemic area documented a rodent irruption during the 3rd year of the study. Both population levels of rodents and the incidence of human cases were low during the first 2 years of the study, but the number of human cases reached a 20-year high during the epidemic season following the rodent irruption (Mills et al., 1992).

Risk factors.-Laboratory handling of 
pathogenic arenaviruses is notoriously risky. Two of the three known infections with Sabiá virus were laboratory acquired (Centers for Disease Control and Prevention, 1994b). Laboratory infections also occurred in the United States and other countries while researchers were studying Lassa, Junín, and Machupo viruses (Johnson et al., 1973; Leifer et al., 1970; Vasconcelos et al., 1993; Weissenbacher et al., 1978). Experiments with these agents that involve working with live virus should be performed only where maximum (biosafety level 4) containment facilities are available (Centers for Disease Control and Prevention and National Institute of Health, 1993).

The natural means of transmission of arenaviral hemorrhagic fever viruses to humans is through direct exposure to infected rodents or their excreta or secreta. Thus, any activities that increase the chance of this occurrence pose a high risk for infection. In the case of Junín virus, farming activity, especially the harvest, brings humans into contact with rodents during the period of peak population density. For Lassa, Machupo, and Guanarito viruses, farming activities also may place residents at risk, but allowing rodents to enter the home appears to be the major risk factor. This latter risk may be mitigated by trapping or poisoning rodents in and around residences and by rodent-proofing human dwellings.

South America seems to be the center of diversity for arenaviruses. Two new pathogenic arenaviruses (Coimbra et al., 1994; Tesh et al., 1994) and one whose pathogenicity is uncertain (J. N. Mills et al., in litt.) have been identified there in the past 5 years; it is certain that others remain to be discovered. Mammalogists and wildlife biologists working in South America should be aware of the potential for infection. They should take precautions when working in the field, be alert for the symptoms of viral hemorrhagic fevers, and report potential exposure to physicians.

Future research.-Directions for future research with hemorrhagic fever viruses span the range from field to theoretical to laboratory investigations. The recent recognition of new viruses (e.g., SNV and Guanarito) is indicative of our relative ignorance of this diverse group of agents. Current laboratory research focuses on characterizing the basic biology of the viruses and pathogenesis of infection in rodents. Other than some preliminary analyses on the effects of virus-host interactions, few studies have been conducted to elucidate the mechanisms of viral persistence, viral shedding and transmission, tissue tropism, and why some rodents are competent reservoir hosts while other, closely related, species become immune. The need for high-containment facilities (biosafety level 4) to conduct work with rodents infected with some viruses means that few institutions are capable of conducting this research.

There are substantial areas of research that need to be addressed by systematists, field mammalogists, and population ecologists. One of the primary issues is the proper identification, characterization, and preservation of rodents implicated as possible reservoirs. Expertise in species identification was critical in identifying the reservoir of Guanarito virus as S. alstoni (Tesh et al., 1993). Detailed ecological studies of Junín virus could not have been conducted without clarifying the rodent reservoir (Mills et al., 1991). The pattern of virus-host relationships between Mastomys and the Lassalike viruses in Africa will become clear only when the genetic relationships among the sibling species of the Mastomys natalensis complex are elucidated (Green et al., 1980; Happold, 1987). Identifying reservoirs has immediate implications for characterizing the spatial distributions of viruses, and consequently, the human population at risk. Knowledge of habitat requirements or preferences of the rodent hosts further refines our knowledge of the at-risk population. The preservation of museum voucher specimens and especially frozen tissues has furthered our ability to rapidly identify 
the geographic range and temporal characteristics of populations of $P$. maniculatus infected with SNV (Baker, 1994). Further detailed ecological studies of rodent hosts are needed to characterize the modes and effects of viral transmission in host populations under natural conditions.

Longitudinal studies of the dynamics of virus infection in rodent populations tracked over years are essential to answer questions concerning demographic processes in virus maintenance and transmission. In few instances are there any quantitative studies relating population density of rodents to incidence or prevalence of virus infection, and even fewer studies have attempted to link these data to the study of human disease. The spatial distribution of virus infection along altitudinal or resource gradients remains unexplored. Molecular biologic methods are permitting detailed analyses of virus and rodent phylogenies, yet the union of these two disciplines is in its infancy. These viruses may provide useful support for phylogenetic relationships among the Rodentia or they may provide clues about the zoogeographic patterns within species. The latter is suggested by the detailed geographic analysis of SNV and $P$. maniculatus in the southwestern United States (Nichol et al., 1993).

The close association between hemorrhagic fever virus and rodent host provides interesting co-evolutionary systems for study. A wide range of virus-host interactions available for study include: causation of varying degrees of pathology in the host; production of chronic infection compared with immune clearance; evolution of vertical or horizontal transmission of viruses within host populations. The entire realm of these interactions is poorly studied in natural systems, but these viruses may provide a basis for testing theories of host-parasite interactions developed in recent years (Anderson and May, 1991).

\section{ACKNOWLEDGMENTS}

We thank C. J. Peters, J. O'Conner, B. Ellis, and an anonymous reviewer for helpful comments on an earlier version of this paper.

\section{Literature Cited}

ANDERson, R. M., AND R. M. MAY. 1991. Infectious diseases of humans: dynamics and control. Oxford University Press, Oxford, United Kingdom, 757 pp.

ArmstronG, C., AND R. D. LiLliE. 1934. Experimental lymphocytic choriomeningitis of monkeys and mice produced by a virus encountered in studies of the 1933 St. Louis encephalitis epidemic. Public Health Report, 49:1019-1027.

ArribalzaGA, R. A. 1955. Una nueva enfermedad epidémica a germen desconocido: hipertermia nefrotóxica, leucopénica y enantemática. Dia Médico, 27: 1204-1210.

Arthur, R. R., R. Lofts, G. E. Glass, J. W. LeDuc, AND J. E. CHILDS. 1992. Grouping of hantaviruses by small (s) genome segment polymerase chain reaction and amplification of viral RNA from wildcaught rats. The American Journal of Tropical Medicine and Hygiene, 47:210-224.

BAKER, R. J. 1994. Some thoughts on conservation, biodiversity, museums, molecular characters, systematics, and basic research. Journal of Mammalogy, 75:277-287.

Brummer-Korvenkontio, M., H. HentTonen, AND A. VAHERI. 1982. Hemorrhagic fever with renal syndrome in Finland: ecology and virology of nephropathia epidemica. Scandinavian Journal of Infectious Diseases, 36(supplement):88-91.

Burek, K. A., C. A. Rossi, J. W. LeDuc, ANd T. M. YuILL. 1994. Serologic and virologic evidence of a Prospect Hill-like hantavirus in Wisconsin and Minnesota. The American Journal of Tropical Medicine and Hygiene, 51:286-294.

Calisher, C. H., R. Tzianabos, R. D. LoRd, AND P. H. Coleman. 1970. Tamiami virus, a new member of the Tacaribe group. The American Journal of Tropical Medicine and Hygiene, 19:520-526.

Carballal, G., C. M. Videla, and M. S. Merani. 1988. Epidemiology of Argentine hemorrhagic fever. European Journal of Epidemiology, 4:259-274.

Centers for Disease Control and Prevention. 1969. Bolivian hemorrhagic fever-La Cayoba, Bolivia. Morbidity and Mortality Weekly Report, 18: 120.

. 1993a. Update: hantavirus pulmonary syndrome-United States, 1993. Morbidity and Mortality Weekly Report, 42:816-820.

1993b. Hantavirus infection-southwestern United States: interim recommendations for risk reduction. Morbidity and Mortality Weekly Report, 42 (no. RR-11):1-13.

1994a. Newly identified hantavirus-Florida, 1994. Morbidity and Mortality Weekly Report, 43: 99-105.

1994b. Arenavirus infection-Connecticut, 1994. Morbidity and Mortality Weekly Report, 43: 635-636.

— . 1994c. Bolivian hemorrhagic fever-El Beni Department, Bolivia, 1994. Morbidity and Mortality Weekly Report, 43:943-946.

Centers for Disease Control and Prevention and National Institute of Health. 1993. Biosafety in microbiological and biomedical laboratories. United 
States Government Printing Office, Washington, D.C., 177 pp.

Childs, J. E., AND C. J. Peters. 1993. Ecology and epidemiology of arenaviruses and their hosts. Pp. 331-384, in The Arenaviridae (M. S. Salvato, ed.). Plenum, New York, 401 pp.

Childs, J. E., G. E. Glass, G. W. Korch, and J. W. LEDUC. 1987a. Prospective seroepidemiology of hantavirues and population dynamics of small mammal communities of Baltimore, Maryland. The American Journal of Tropical Medicine and $\mathrm{Hy}-$ giene, 37:648-662.

. 1989. Effects of hantaviral infection on survival, growth and fertility in wild rat (Rattus norvegicus) populations of Baltimore, Maryland. Journal of Wildlife Diseases, 25:469-476.

Childs, J. E., G. E. Glass, G. W. Korch, T. G. KsiAZEK, AND J. W. LEDUC. 1992. Lymphocytic choriomeningitis virus infection and house mouse (Mus musculus) distribution in urban Baltimore. The American Journal of Tropical Medicine and $\mathrm{Hy}-$ giene, 47:27-34.

ChIlds, J. E., G. W. Korch, G. E. Glass, J. W. LeDuc, AND K. V. SнAн. 1987 b. Epizootiology of hantavirus infections in Baltimore: isolation of a virus from Norway rats, and characteristics of infected rat populations. American Journal of Epidemiology, 126: $55-68$.

Childs, J. E., G. W. Korch, G. A. Smith, A. D. Terry, AND J. W. LeDUC. 1985. Geographical distribution and age-related prevalence of Hantaan-like virus in rat populations of Baltimore, Maryland, U.S.A. The American Journal of Tropical Medicine and $\mathrm{Hy}-$ giene, 34:385-387.

CHILDS, J. E., ET AL. 1994. Serologic and genetic identification of Peromyscus maniculatus as the primary rodent reservoir for a new hantavirus in the southwestern United States. Journal of Infectious Diseases, 169:1271-1280.

Colmbra, T. L. M., ET AL. 1994. New arenavirus isolated in Brazil. The Lancet, 343:391-392.

Cooper, C. B., W. R. Gransden, and M. Webster. 1982. A case of Lassa fever: experience at St. Thomas's Hospital. British Medical Journal, 285:10031005.

Davis, D. E., J. T. EmLen, AND A. W. Stokes. 1948. Studies on home range in the brown rat. Journal of Mammalogy, 29:207-225.

De Villafañe, G., ET Al. 1977. Dinámica de las comunidades de roedores en agroecosistemas pampásicos. Medicina, 37, suppl. 3:128-140.

Desmyter, J., J. W. LeDuc, K. M. Johnson, F. BrasSeur, C. Deckers, and C. van Ypersele de StrIHOU. 1983. Laboratory rat associated outbreak of haemorrhagic fever with renal syndrome due to Hantaan-like virus in Belgium. The Lancet, 2:14451448.

DouRnON, E., ET AL. 1984. HFRS after a wild rodent bite in the Haute-Savoie and risk of exposure to Hantaan-like virus in a Paris laboratory. The Lancet, 1:676-677.

Downs, W. G., C. R. Anderson, L. SPence, T. H. G. AitKEN, AND A. H. GreEnHall. 1963. Tacaribe virus, a new agent isolated from Artibeus bats and mosquitoes in Trinidad, West Indes. The American
Journal of Tropical Medicine and Hygiene, 12:640 646.

DuCHIN, J. S., ET AL. 1994. Hantavirus pulmonary syndrome: a clinical description of 17 patients with a newly recognized disease. New England Journal of Medicine, 330:949-955.

ElLIOTT, L. H., ET AL. 1994. Isolation of the causative agent of hantavirus pulmonary syndrome. The American Journal of Tropical Medicine and $\mathrm{Hy}$ giene, 51:102-108.

ForThAL, D. N., S. P. BAUER, AND J. B. MCCORMICK. 1987. Antibody to hemorrhagic fever with renal syndrome viruses (hantaviruses) in the United States. American Journal of Epidemiology, 126: $1210-1213$

GAJDUSEK, G. C. 1989. Introduction. Pp. 1-10, in Manual of hemorrhagic fever with renal syndrome (H. W. Lee and J. Dalrymple, eds.). Korea University, Seoul, 137 pp.

Glass, G. E., J. E. Childs, G. W. KorCh, and J. W. LEDuC. 1988. Association of intraspecific wounding with hantaviral infection in wild rats (Rattus norvegicus). Epidemiology and Infection, 101:459472.

Glass, G. E., A. J. Watson, J. W. LeDuc, G. D. KeLEN, T. C. QuinN, AND J. E. Childs. 1993. Infection with a rat-borne hantavirus in United States residents is consistently associated with hypertensive renal disease. Journal of Infectious Diseases, 167:614 619.

Green, C. A., H. Keogh, D. H. Gordon, M. Pinto, AND E. K. HaRTwig. 1980. The distribution, identification, and naming of the Mastomys natalensis species complex in southern Africa (Rodentia: Muridae). Journal of Zoology (London), 192:17-23.

HAPPOLD, D. C. D. 1987. The mammals of Nigeria Oxford Science Publications, Clarendon Press, Oxford, United Kingdom, 402 pp

Health Canada. 1994. First reported cases of hantavirus pulmonary syndrome in Canada. Canada Communicable Disease Report, 20-15:121-125.

HJElle, B., ET AL. 1994. Genetic identification of a novel hantavirus of the harvest mouse Reithrodontomys megalotis. Journal of Virology, 68:67516754.

Holmes, G. P., ET AL. 1990. Lassa fever in the United States. Investigation of a case and new guidelines for management. New England Journal of Medicine, 323:1 120-1123.

HUA-XIN, C., AND Q. FU-XI. 1993. Epidemiologic surveillance on the hemorrhagic fever with renal syndrome in China. Chinese Medical Journal, 106:857863.

JoHNSON, K. M. 1985. Arenaviruses. Pp. 1033-1053, in Virology (B. N. Fields and K. N. Knipe, eds.). Raven Press, New York, 1,614 pp.

1989. Arenaviruses. Pp. 133-152, in Viral infections of humans (A. S. Evans, ed.). Plenum Medical Book Company, New York, 829 pp.

Johnson, K. M., P. A. WEBB, AND G. JUSTINES. 1973. Biology of Tacaribe-complex viruses. Pp. 241-258, in Lymphocytic choriomeningitis virus and other arenaviruses (F. Lehmann-Grube, ed.). Springer-Verlag, Inc., New York, 339 pp.

Johnson, K. M., P. TAYlor, L. H. Elliott, and O. 
TOMORI. 1981. Recovery of a Lassa-related arenavirus in Zimbabwe. The American Journal of Tropical Medicine and Hygiene, 30:1291-1293.

Kaufman, G. A., D. W. Kaufman, B. R. McMillan, AND D. E. BRILlharT. 1994. Prevalence of hantavirus antibodies in natural populations of deer mice in north central Kansas. The Prairie Naturalist, 26: 209-216.

Korch, G. W., J. E. Childs, G. E. Glass, C. A. Rossi, AND J. W. LEDUC. 1989. Serologic evidence of hantaviral infections within small mammal communities of Baltimore, Maryland: spatial and temporal patterns and host range. The American Journal of Tropical Medicine and Hygiene, 41:230-240.

KRAVETZ, F. O. 1977. Ecología y control de reservorios. Ciéncia e Investigación, 33:235-242.

Kulagin, S. M., N. I. Fedorova, and E. S. Ketiladze. 1962. Laboratory outbreak of hemorrhagic fever with renal syndrome (clinico-epidemiological characteristics). Journal of Microbiology, Epidemiology, and Immunology (in Russian), 33:121-126.

KUNS, M. 1965. Epidemiology of Machupo virus infection. II. Ecological and control studies of hemorrhagic fever. The American Journal of Tropical Medicine and Hygiene, 14:813-816.

LEDuC, J. W. 1987. Epidemiology of Hantaan and related viruses. Laboratory Animal Science, 37:413418.

418. 1989. Epidemiology of hemorrhagic fever viruses. Reviews of Infectious Disease, 11, suppl. 4: S730-S735.

LeDuc, J. W., G. A. Smith, And K. M. Johnson. 1984. Hantaan-like viruses from domestic rats captured in the United States. The American Journal of Tropical Medicine and Hygiene, 33:992-998.

LEDUC, J. W., ET AL. 1986. Global survey of antibody to Hantaan-related viruses among peridomestic rodents. Bulletin of the World Health Organization, 64:139-144.

LEE, H. W. 1982. Korean hemorrhagic fever. Progress in Medical Virology, 28:96-113.

1989. WHO collaborating center for virus reference and research. Pp. 11-18, in Manual of hemorrhagic fever with renal syndrome $(\mathrm{H}$. W. Lee and J. M. Dalrymple, eds.). Korea University, Seoul, $137 \mathrm{pp}$.

LEE, H. W., AND K. M. JohNSON. 1982. Laboratoryacquired infections with Hantaan virus, the etiologic agent of Korean hemorrhagic fever. Journal of Infectious Diseases, 146:645-651.

LEE, H. W., L. J. BAEK, AND K. M. JoHNSON. $1982 a$. Isolation of Hantaan virus, the etiologic agent of Korean hemorrhagic fever, from wild urban rats. Journal of Infectious Diseases, 146:638-644.

LEE, H. W., P. W. LEE, AND K. M. Johnson. 1978. Isolation of the etiologic agent of Korean hemorrhagic fever. Journal of Infectious Diseases, 137: 298-308.

Lee, H. W., G. R. French, P.-W. Lee, L. J. Baek, K. TsUCHIYA, AND R. S. FoulKe. 1981. Observations on natural and laboratory infection of rodents with the etiologic agent of Korean hemorrhagic fever. The American Journal of Tropical Medicine and $\mathrm{Hy}-$ giene, 30:477-482.

LeE, H. W., I. W. Seong, L. J. BAeK, D. A. Mcleod,
S. S. SEO, AND C. Y. KANG. 1984. Positive serological evidence that Hantaan virus, the etiologic agent of hemorrhagic fever with renal syndrome, is endemic in Canada. Canadian Journal of Microbiology, 30:1137-1140.

Lee, P.-W., H. L. Amyx, R. Yanagihara, D. C. GajDuseK, D. Goldgaber, and C. J. GibBS, JR. 1985. Partial characterization of Prospect Hill virus isolated from meadow voles in the United States. Journal of Infectious Diseases, 152:826-829.

Lee, P.-W., R. Yanagihara, M. Franko, H. L. Amyx, C. J. Gibis, JR., AND D. C. GajduseK. 1982 $b$. Preliminary evidence that Hantaan or a closely related virus is enzootic in domestic rodents. New England Journal of Medicine, 307:624-625.

LeIFER, E., D. J. GoCKE, AND H. Bourne. 1970. Lassa fever, a new virus disease of man from West Africa. II. Report of a laboratory-acquired infection treated with plasma from a person recently recovered from the disease. The American Journal of Tropical Medicine and Hygiene, 19:677-679.

Linderholm, M., A. Billstrom, B. Settergren, AND A. TARNVIK. 1992. Pulmonary involvement in nephropathia epidemica as demonstrated by computed tomography. Infection, 20:263-266.

Lloyd, G., AND N. JoNES. 1986. Infection of laboratory workers with hantavirus acquired from immunocytomas propagated in laboratory rats. Journal of Infection, 12:117-125.

Lloyd, G., E. T. W. Bowen, N. Jones, AND A. PEndRy. 1984. HFRS outbreak associated with laboratory rats in UK. The Lancet, 2:1175-1176.

MACKenZIE, R. B. 1965. Epidemiology of Machupo virus infection. I. Pattern of human infection, San Joaquín, Bolivia, 1962-1964. The American Journal of Tropical Medicine and Hygiene, 14:808-813.

Mackenzie, R. B., H. K. Beye, L. V. VAlverde-CH, AND H. GarRón. 1964. Epidemic hemorrhagic fever in Bolivia. I. A preliminary report of the epidemiologic and clinical findings in a new epidemic area in South America. The American Journal of Tropical Medicine and Hygiene, 13:620-625.

Maiztegui, J. I., A. Briggiler, D. EnRia, ANd M. R. Feuillade. 1986. Progressive extension of the endemic area and changing incidence of Argentine hemorrhagic fever. Medical Microbiology and Immunology, 175:149-152.

MCCORMICK, J. B., ET AL. 1987. A case-control study of the clinical diagnosis and course of Lassa fever. Journal of Infectious Diseases, 155:445-455.

MCKenNA, P., ET AL. 1992. Eradication of hantavirus infection among laboratory rats by application of caesarian section and a foster mother technique. Journal of Infection, 25:181-190.

MerCADO, R. R. 1975. Rodent control programmes in areas affected by Bolivian haemorrhagic fever. Bulletin of the World Health Organization, 52:691-696.

Mills, J. N., ET AL. 1991. Junín virus activity in rodents from endemic and nonendemic loci in central Argentina. The American Journal of Tropical Medicine and Hygiene, 44:589-597.

1992. A longitudinal study of Junín virus activity in the rodent reservoir of Argentine hemorrhagic fever. The American Journal of Tropical Medicine and Hygiene, 47:749-763. 
1994. Prevalence of infection with Junín virus in rodent populations in the epidemic area of Argentine hemorrhagic fever. The American Journal of Tropical Medicine and Hygiene, 51:554-562.

MONATH, T. P. 1990. Ribavirin interferon and antibody approaches to prophylaxis and therapy for viral hemorrhagic fevers. Current Opinion in Infectious Diseases, 3:824-833.

Nichol, S. T., ET AL. 1993. Genetic identification of a novel hantavirus associated with an outbreak of acute respiratory illness in the southwestern United States. Science, 262:914-917.

NikLasson, B., ET AL. 1993. An epidemiologic study of hemorrhagic fever with renal syndrome in Bashkirostan (Russia) and Sweden. The American Journal of Tropical Medicine and Hygiene, 48:670-675.

Nuzum, E. O., C. A. Rossi, E. H. Stephenson, and J. W. LEDUC. 1988. Aerosol transmission of Hantaan and related viruses to laboratory rats. The American Journal of Tropical Medicine and Hygiene, 38:636640.

NYSTRÖM, K. 1982. Epidemiology of HFRS (endemic benign nephropathy-EBN) in Sweden. Scandinavian Journal of Infectious Diseases (Supplement), 36:192.

Pan American Health Organization. 1982. Bolivian hemorrhagic fever. Epidemiological Bulletin, Pan American Health Organization, 3:15-16.

PARMENTER, R. R., AND R. VIGIL. 1993. The HARDS epidemic in the Southwest: an assessment of autumn rodent densities and population demographics in central and northern New Mexico, October, 1993. Sevilleta Long Term Ecological Research Publication, 45:1-7.

Peters, C. J. 1991. Arenaviruses. Pp. 541-570, in Textbook of human virology (R. B. Belshe, ed.). Mosby Year Book, Inc., St. Louis, Missouri, 1,064 pp.

Peters, C. J., R. W. Kuehne, R. R. Mercado, R. H. Le Bow, R. O. Spertel, and P. A. Webb. 1971. Hemorrhagic fever in Cochabamba, Bolivia, 1971. American Journal of Epidemiology, 99:425-433.

Rollin, P. E., ET AL. In press. Isolation of Black Creek Canal virus, a new hantavirus from Sigmodon hispidus in Florida. Journal of Medical Virology.

Sabattini, M. S., and M. S. Contigiani. 1982. Ecological and biological factors influencing the maintenance of arenaviruses in nature, with special reference to the agent of Argentinean haemorrhagic fever (AHF). Pp. 251-262, in International symposium on tropical arboviruses and haemorrhagic fevers (F. D. Pinheiro, ed.). Academia Brasilera de Ciencias, Rio de Janiero, Brazil, 481 pp.

Sabattini, M. S., L. E. Gonzalez de Rios, G. Diaz, AND V. R. VEGA. 1977. Infección natural y experimental de roedores con virus Junín. Medicina, 37: 149-161.

SALAS, R., ET AL. 1991. Venezuelan haemorrhagic fever-a severe multisystem illness caused by a newly recognized arenavirus. The Lancet, 338:1033-1036.

SCHMalJohn, C. S., A. L. SChMALJOHN, AND J. M. DALRYMPLE. 1987. Hantaan virus mRNA: coding strategy, nucleotide sequence, and gene order. Virology, 157:31-39.

Schmaljohn, C. S., G. B. Jennings, J. Hay, and J. M.
DALRYMPLE. 1986. Coding strategy of the S genome segment of Hantaan virus. Virology, 155:633-643.

Schmaljohn, C. S., ET AL. 1985. Antigenic and genetic properties of viruses linked to hemorrhagic fever with renal syndrome. Science, 227:1041-1044.

Sulin, S. E., AND R. M. Pike. 1969. Prevention of laboratory infections. Pp. 68-78, in Diagnostic procedures for viral and rickettsial diseases (E. H. Lennette and N. J. Schmidt, eds.). American Public Health Associations, New York, 978 pp.

TANishita, O., ET AL. 1986. Persistent infection of rats with haemorrhagic fever with renal syndrome virus and their antibody responses. Journal of General Virology, 67:2819-2824.

Tesh, R. B., P. B. Jahrling, R. Salas, and R. Shope. 1994. Description of Guanarito virus (Arenaviridae: Arenavirus), the etiologic agent of Venezuelan hemorrhagic fever. The American Journal of Tropical Medicine and Hygiene, 50:452-459.

TESH, R. B., ET AL. 1993. Field studies on the epidemiology of Venezuelan hemorrhagic fever: implication of the cotton rat Sigmodon alstoni as the probable rodent reservoir. The American Journal of Tropical Medicine and Hygiene, 49:227-235.

TsaI, T. F. 1987. Hemorrhagic fever with renal syndrome: mode of transmission to humans. Laboratory Animal Science, 37:428-430.

TsAI, T. F., ET AL. 1985. Serological and virological evidence of a Hantaan virus-related enzootic in the United States. Journal of Infectious Diseases, 152: 126-136.

UMENAI, T., ET AL. 1979. Korean haemorrhagic fever in staff in an animal laboratory. The Lancet, 1:1314 1316.

Vasconcelos, P. F., A. P. Travassos da Rosa, S. G. Rodrigues, R. Tesh, J. F. S. Travassos da Rosa, and E. S. Travassos DA Rosa. 1993. Infeccao humana adquirida em laboratorio causada pelo virus SPH 114202 (Arenavirus: familia Arenaviridae): aspectos clinicos e laboratoriais. Reviste Instituto Medicina Tropical Sao Paulo, 35:521-525.

Vitullo, A. D., AND M. S. Merani. 1990. Vertical transmission of Junín virus in experimentally infected adult Calomys musculinus. Intervirology, 31: 339-344.

WebB, P. A., K. M. Johnson, R. B. MACKenZIE, AND M. L. KUnS. 1967. Some characteristics of Machupo virus, causative agent of Bolivian hemorrhagic fever. The American Journal of Tropical Medicine and Hygiene, 16:531-538.

WEISSENBACHER, M. C., ET AL. 1978. Inapparent infection with Junín virus among laboratory workers. Journal of Medical Virology, 6:223.

Woodruff, A. W., T. P. Monath, A. A. F. Mahmoud, A. K. PAin, AND C. A. Morris. 1973. Lassa fever in Britain: an imported case. British Medical Journal, 2:1173.

XiaO, S.Y., Y. K. Chu, F. K. Knauert, R. Lofts, J. M. DAIR YMPLE, AND J. W. LeDuc. 1992. Comparison of hantavirus isolates using a genus-reactive primer pair polymerase chain reaction. Journal of General Virology, 73:567-573.

Yanagihara, R., H. L. AmyX, and D. C. Gajdusek. 1985a. Experimental infection with Puumala virus, the etiologic agent of nephropathia epidemica, in 
bank voles (Clethrionomys glareolus). Journal of $\mathrm{Vi}-$ rology, 55:34-38.

Yanagihara, R., D. C. Gajdusek, C. J. GibBs, JR., AND R. TRAUB. 1984. Prospect Hill virus: serological evidence for infection in mammalogists. New England Journal of Medicine, 310:1325-1326.

1987. Serological survey of Prospect Hill virus infection in indigenous wild rodents in the USA Transactions of the Royal Society of Tropical Medicine and Hygiene, 81:42-45.
YANAGIHARA, R., ET AL. 1985b. Serological evidence of Hantaan virus infection in the United States. The American Journal of Tropical Medicine and Hygiene, 34:296-399.

ZEITZ, P. S., ET AL. 1995. Epidemiology and risk factors for hantavirus pulmonary syndrome in the southwestern United States. Journal of Infectious Diseases, 171:864-870. 